Dr. Ebtesam M.M. El-Shokrofy

\title{
The Significance of Place in Sartre's No Exit, Enani's Younis'Sweet and El-Asal's Women's Prison
}

\author{
Ebtesam M.M. El-Shokrofy \\ Associate Professor in English Literature \\ Faculty of Education - Damanhur University
}

\section{Introduction}

The complex systems theory is a theory of interdisciplinary studies applied to humanities, in general, and literature, in particular. According to William H. Newell (2001), this theory is based on four corners. Firstly, any literary study should apply multi- disciplines in order to be called interdisciplinary. Secondly, an interdisciplinary study should provide definitions of the terms used from such diverse fields. Thirdly, there should be common grounds among these disciplines through widespread application and extension of meaning. Lastly, human behavior should be always at the core of any literary study.

Methodologically, this paper attempts to pinpoint the significance of place as represented in Jean - Paul Sartre's No Exit, Mohammad Enani's Younis' Sweet and Fathiyya elAsal's Women's Prison, drawing on the complex system theory as tackled by William H. Newell. The researcher, thus, discusses place from geographical, sociological, philosophical and environmental points of view, providing many definitions from all these diverse human sciences, finding three common grounds among these fields (definition of place, sense of place, spirit of place) and concluding that people's sense of place matters most. 
The present paper has three objectives. First, it discusses the dramatic importance of some enclosed places as represented in the three selected plays. In these plays, the actions take place in hell, a holding cell or a prison, respectively. The setting is only four walls and a closed door. So, it is the place which is foregrounded here, not action, nor characters. The place becomes the hero. Thus, the dramatic conflict is no longer among characters as in classical drama, but between them and the place. Second, it focuses on how place affects people's relation to one another as well as their relation to place. Imprisoned as they are inside such places, characters begin to acquire a certain sense of place. The paper concludes that despite the fact that place is nearly the same in the three plays, with the same spirit (punishment, confession, reformation, etc.); the characters' sense of place is different. Finally, the paper calls for more attention to be paid to both the study of place as an important element in drama and the applications of interdisciplinary studies of place to literature.

Key Words: Definition of place, sense of place, spirit of place

According to William Newell, "interdisciplinary study draws insights from relevant disciplines and integrates those insights into a more comprehensive understanding"(2001, p.2). So, place is the core of many human sciences including sociology, geography, philosophy, environmental psychology, among many others. Diverse as these fields are, they have three grounds in common regarding place definition of place, sense of place and spirit of place. According to these fields, a place is any space occupied by human beings - be it public or private, open or closed and

\section{ELLS Vol.8 No.I (156) December 2017}




\section{Dr. Ebtesam M.M. El-Shokrofy}

other different classifications in terms of ownership, control and access. Sense of place means place attachment or the relation between people and place, whether it is positive or negative, weak or strong, etc. The spirit of place means the general and particular characteristics attributed to any place.

Since William Newell states that "Complex systems theory brings out the under-recognized need for disciplinarians to scrutinize and frequently modify terminology used by contributing disciplines...definitions become especially important when comparing insights from different disciplines" (2001,p.19), further definitions of the three key words of this paper should be discussed fully before application.

Wherever cited, all definitions of place relate it to the people living in it. These definitions stress the fact that place only exists wherever people are. Three different definitions will be quoted as examples.

From the geographical point of view, Tim Cresswell begins his book, Place: A Short Introduction by defining place as "a word that seems to speak for itself...Place is not a specialized piece of academic terminology...place is everywhere"(2004, p.1-2). Creswell adds that any meaningful space is called a place. "This is the most straightforward and common definition of place - a meaningful location"(Ibid, p.7).

Another geographer, $\mathrm{Yi}-\mathrm{Fu}$ Tuan completes Cresswell's definition by adding that:

Place, however, has more substance than the word location suggests: it has a unique entity...it has a history and meaning. Place 
The Significance of Place in Sartre's No Exit, Enani's Younis'Sweet and El-Asal's Women's Prison

incarnates the experience and aspirations of a people. Place is not only a fact to be explained in the broader frame of space, but it is also a reality to be clarified and understood from the perspectives of the people who have given it meaning (1979,p.387).

A third geographer, David Harvey, stresses the social aspect of the definition. According to Harvey, "Places are constructed and experienced as material ecological artifacts and intricate networks of social relations... They are an intense focus of discursive activity, filled with symbolic and representational meanings, and they are a distinctive product of institutionalized social and political economic power" (1996, p.316).

In her definition of place, Lucy Lippard, the geographer, depends on a comparison between place and landscape as follows: "A lived-in landscape becomes a place, which implies intimacy; a once-lived-in landscape can be a place, if explored, or remain a landscape, if simply observed...Landscape can only be seen from outside, as a backdrop for the experience of viewing"(1997, p.7-8).

Like geographers, philosophers headed by Edward Casey, stress the human aspect of place. Comparing space to place, Casey concludes that place is primary.

"Both geography and phenomenology have come to focus on place as experienced by human beings, in contrast to space, whose abstractness discourages experiential explorations"(2001, p.683).

\section{ELLS Vol.8 No.I (158) December 2017}


Environmental psychologists like Setha Low and Irwin Altman also relate place to people. According to them, "place, in our general lexicon, refers to space that has been given meaning through personal, group, or cultural processes"(1992, p.5).

It is obvious from the abovementioned definitions of place that place and people are two sides of the same coin. This is called place attachment or sense of place. In its simplest definitions, place attachment or sense of place means the relationship between people and the place where they live. Below are four human sciences providing different definitions of the sense of place. Geographer Edward Relph defines the sense of place in terms of 'insideness' and 'outsideness' according to the degree of attachment, involvement and concern that a person or group has for a particular place (1976, p.49).

In sociology, David Hummon defines the sense of place as:

People's subjective perceptions of their environments and their more or less conscious feelings about those environments. The sense of place is inevitably dual in nature, involving both an interpretive perspective on the environment and an emotional reaction to the environment... Sense of place involves a personal orientation toward place, in which one's understanding of place and one's feeling about place become fused in the context of environmental meaning (1992, p.262). 
In this regard, Hummon defines five types of the sense of place. They are ideological rootedness, taken for granted rootedness, place relativity, place alienation and placelessness (Ibid, p. 264). In his own commentary on this division, Jennifer Cross adds: "Each type can be described by a person's level of attachment, identification and involvement with the community, past experiences and future expectations, and their assessment of the place"(2001, p.8-9).

In environmental psychology, Setha Low describes the sense of place as "the symbolic relationship formed by people giving culturally shared emotional/affective meanings to a particular space or piece of land that provides the basis for the individual's and group's understanding of and relationship to the environment"(1992, p.165). Like David Hummon, Setha Low categorizes six types of symbolic linkage of people and place- genealogical, economic, cosmological, narrative, cultural as well as linkage through loss of land or destruction of community (Ibid, p. 166).

From a philosophical point of view, Edward Casey subjectively defines the sense of place as follows: "When I inhabit a place - whether by moving through it or staying in it - I have it in my actional purview. I also hold it by virtue of being in its ambiance- first in my body as it holds onto the place by various sensory and kinesthetic means, then in my memory as I "hold it in mind" (2001, p.687).

There are two factors affecting people's sense of place. The first factor is related to the people themselves. In this regard, environmental psychologists state that people's continuous and regular routine activities in any place create

\section{ELLS Vol.8 No.I (160) December 2017}




\section{Dr. Ebtesam M.M. El-Shokrofy}

and deepen people's sense of their place and add more to their interpersonal cooperation. (Buttimer\&Seamon, 1980, p.159, 162).

To the same effect, human landscape writers add another effective element of sense of place - place identity. Marcel Hunziker and others state that people's sense of place makes them feel responsible for such place so as "its loss or damage threatens the group's or person's self-identity (2007, p.53).Feeling responsible for their place, people can make changes to place to suit them and their identity. Hunziker adds:

And as identity development is a life-long process, a person may not feel well at a place unless he or she can periodically re-appropriate the place, which allows that person to update and develop his or her identity. Thus, individuals can establish a place identity in places which are characterized by continuity, yet at the same time offer them sufficient opportunities for appropriating the settings and leaving individual and collective traces there (Ibid,p.54).

Another human landscape writer, Rachelle Lopez, defines four factors affecting sense of place. To her, personal experience inside the place comes first. "The specific experience a person has in a particular setting, and how that setting causes him or her to feel, is what directs and molds an individual's sense of place"(2010, p.46). The next is the frequency of experience. Repeated experiences in the same place "facilitate a person's ability to increase their sense of place more than if only a single experience was presented in

\section{ELLS Vol.8 No.I (161) December 2017}


The Significance of Place in Sartre's No Exit, Enani's Younis'Sweet and El-Asal's Women's Prison

the area"(Ibid, p.49). Then, people's behavior and their conceptualizations of place affect their sense of place. "Personal differences that may be displayed by different individuals stem from these differences that exist between people, their concept of place, and the interactions they have had and continue to have with their surroundings"(Ibid,p.48). Lastly, people's expectations and future plans. "People's perception of a place also varies depending on their purpose or goal for being there as well as their expectations"(Ibid, p.48).

The second factor that affects people's sense of place is related to the place itself. This is called the spirit of place. It means the general and particular characteristics attributed to any place. Many other terms like identity, personality and character are alternatively used by different writers to define the spirit of place. Geographer Edward Relph defines spirit of place as place identity or "Persistent sameness and unity which allows that place to be differentiated from others"(1976, p.45).Yi-Fu -Tuan defines it as personality of place: "Personality suggests the unique: places, like human beings, acquire signature in the course of time"(1979, p. 409). Rachelle Lopez calls it character of place which is "unique and maintains a character of its own that makes it stand apart from other areas"(2010, p.46).

The question here is how can such studies of place, sense of place and spirit of place be applied to this paper? After discussing these definitions, one feels that all these places are on the positive side. The reader assumes that these places to which people are connected may be one's home, country, or any other favorite place. Few believe that people may linger in such closed places as prisons or holding cells. In their introduction to Place Attachment, Setha Low and

\section{$\begin{array}{lllll}\text { ELLS Vol.8 No.I (162) December } 2017 & \end{array}$}




\section{Dr. Ebtesam M.M. El-Shokrofy}

Irwin Altman state that the focus of place studies is always on places like "laden places, such as homes, childhood environment, sacred places, and residences for the elderly"(1992, p.2). No study of place - to my own knowledge -focuses on the bonding of people to these enclosed places, applying theories of place.

The answer lies in two criteria. The first is the flexibility of these studies and their possible application to any place. Geographer Stephen Daniels better expresses it: "Place should be seen as a fluent not a fixed concept, not a settlement in the field of enquiry but a contested terrain"(1992, p.314).Yi-Fu Tuan also states that the spirit of place can be applied differently to any place. When speaking about buildings, monuments and other places, Tuan declares that, "the spirit of place is applicable to them, but in a sense different from holy places in which spirits are believed to dwell literally"(1979, p.416). The second criterion is what William Newell himself calls "extension of the meaning or range of application of a concept"(2001, p.21).

Thus, in the following section of this paper, these closed places, like any other place having both sense and spirit, are to be studied. Place in the present three plays is the same- a bare room with nothing but four walls and a closed door. In Fathiyya el-Asal's Women's Prison, it is a prison divided into separate rooms where some female characters are imprisoned for different reasons and crimes. In Mohammad Enani's Younis' Sweet, it is a holding cell where four men and a woman are kept on custody for the same crime. Jean - Paul Sartre's No Exit takes place neither at a prison nor a holding cell. However, it shares the other two plays the idea of closed rooms as a punishment, especially as 
The Significance of Place in Sartre's No Exit, Enani's Younis'Sweet and El-Asal's Women's Prison

Sartre wrote it directly after his prison experience in 1944. It was first entitled Behind Closed Doors.

In No Exit, actions take place inside a closed room with two women and a man; all are supposed to be in hell for their ex-crimes. This is a common feature of the twentieth century literature where there is: "The idea of the varieties of enclosures that serve as major settings in all literary genres. In such places, whether they function as an individual or a collective prison, as a paradigm of hell or cell, time tends to take the" form of space": experience becomes spatialized." (Witt, 1985, p.11).Witt adds that:

For literary purposes, a prison does not have to be in a state penal institution or a cell with iron bars. A description of any type of enclosed space becomes a prison through an interaction among the points of view of the author, the character portrayed as imprisoned, and the reader or viewer...A prison also may be defined through binary opposition as between open and closed, nature and artifice, motion and motionlessness, time and timelessness, power and powerlessness, imprisoner and imprisoned (Ibid, p.14).

Being nearly the same in the three plays, place has the same characteristics. The most common characteristics of this place are history of place, place of punishment, place of confession, place of co-operation, place where there is continuity between the inside and the outside worlds and a place where there is a continuity of the past and the present. These characteristics are enough to call this closed place a prison (including No Exit).

\section{ELLS Vol.8 No.I (164) December 2017}


The first characteristic of any place is its history. YiFu Tuan states that: "Within the humanistic tradition places have been studied from the historical and literary-artistic perspectives"(1979, p.388). Historically, as Thomas Freeman states, prisons witnessed a great change in the sixteenth and seventeenth centuries due to the great number of writers who were imprisoned at this time. Writers such as Thomas More, Thomas Wyatt, Thomas Dekker, Ben Jonson, among many others, stressed the social function of prison. Thus, the view of prison changes from a place of punishment to a place of reformation or as it is widely known as a 'house of correction'. A shift in attitude towards crimes and prisoners has also taken place. Crimes used to be viewed as offence against God, and hence the prisoner or the criminal should be put to repentance. By the time, crimes become known as an offense against the social order, and that the criminal is seen as being outside the society and should belong to it again. By the end of the sixteenth century, bridewells were largely built. These were "Places of vocational training and rigorous discipline" where people have been kept for no particular crimes and sentenced to no fixed periods. Meanwhile, bridewells become ordinary jails till the present time. (2009, p.133-8).

The idea of punishment as attributed to prison as a second feature is fully understood by all characters in the three plays. Once the three characters in No Exit enter their prison or hell, they express their expectations of all kinds of torture. Garcin is the first to enter. He keeps asking about "the instruments of torture...the racks and red-hot pincers and all the other paraphernalia" (1989, p.4).Inez enters next, mistaking Garcin as the torturer. When Inez does not find her friend Florence, she realizes that this is a kind of torture, 
The Significance of Place in Sartre's No Exit, Enani's Younis'Sweet and El-Asal's Women's Prison

\begin{abstract}
"Ah, that's the way it works, is it? Torture by separation"(Ibid, p.8). Estelle is the last to enter. Finding Garcin hiding his face with his hands, she cries" No. Don't look up. I know what you're hiding with your hands. I know you have no face left". Told that Garcin is not the torturer, Estelle responds, "I thought someone was trying to play a rather nasty trick on me"(Ibid, p. 10). Since there is no torturer there, Inez realizes that they are imprisoned together to torture one another. "I mean that each of us will act as torturer of the two others"(Ibid, p.17).
\end{abstract}

By the same token, characters in Younis'Sweet are used to torture each other in such a holding cell. When all of them make noise, the police officer threatens them: "Listen well! When back, I will smash heads of trouble - makers, if any " (Enani, 1993, p.8, translation mine) ${ }^{1}$. When Baely and Mesqawi fight inside the cell, Atrees threatens them to call the officer, who in turn, "Will keep on crushing their bones till dawn" (Ibid, p.19). The prisoners themselves admit that they deserve any punishment for their ill behavior. Masoud tells the others: "Beware! We will wound each other. It serves us right (In fur). It's our nature; slaughtering each other to feel good. Simply, we are mean curs; ungrateful ones."(Ibid, p. 19-21). Near the end of the play when the lawyer, who pretends to be one of the prisoners, makes noise, the police officer threatens to put him into a secret place. It is understood from the conversation that this place is a place of punishment. The other prisoners are anxious about him "You do not know how this coop looks like. Without referral or release, you will never be out "(Ibid, p.28).

${ }^{1}$.All quotations from this play are translated by the researcher. The translation of the title is approved by the author himself.

ELLS Vol.8 No.I

(166)

December 2017 
Similarly, characters in Women's Prison are kept in closed cells, waiting for their release, or condemnation. According to Salwa, prison's cell is better than the holding cell. To Laila's astonishment, prison is a punishment not only for the guilty but also for the innocent. "Is it possible that the innocent may remain imprisoned"(el-Asal, 1983, p.42, translation mine $)^{2}$.The utmost punishment to Saniya is that prison cuts her off from the outside world. For Salwa, even if the prison is a punishment, it will remain unforgettable experience. These different experiences about the same place is what Sten Moslund calls "The genius of place...the multiple place-worlds and modalities of experience that cooccur within a single place"(2010, p.9).

The third characteristic of prison is the idea of confession. Being enclosed inside prison; characters confess their crimes and sins, rethinking of their future. Jean -Paul Sartre states: "To reveal is to change and that one can reveal only by planning to change"(qtd in.Loeb, 1961, p.287).In Younis'Sweet, and through the use of metadrama (a play inside the play), Mamdouh - the lawyer and his son, act the role of prisoners to spy on the others and trap them into confession. Considering him a stranger, the prisoners ask Mr. Mamdouh for his advice, and here he beats them. It is obvious that the five characters are involved in the same crime-drug selling and cheating. One by one, the five characters confess how far they are involved. The actions reach climax when Younis -the real son of Mamdouh pretends death as a result of eating a piece of sweet sold to prisoners through the prison window. The sweet is nothing but drugs. Through the use of word play, the prisoners got their needs from outside. Words such as piaster, sweet,

${ }^{2}$.All quotations from this play are translated by the researcher.

\begin{tabular}{lllll}
\hline \hline ELLS Vol.8 No.I & (167) December 2017
\end{tabular}


The Significance of Place in Sartre's No Exit, Enani's Younis'Sweet and El-Asal's Women's Prison

pound and sprout beans are used to link the two worlds together-the inside and the outside.

On seeing the young boy dead, the four male characters tell the truth about Mohammad Ghazal, their main partner. Sadia, the only female character, has been released before on purpose, to be followed by the police officers who end the play telling Mamdouh "We've watched Sadia and collected all packets hidden everywhere at her home". In a few minutes, she came up with what would have needed long hours for us to get" (Enani, 1993, p.33). Place, thus, is the stimulus for confession. In this one act play; actions develop rapidly with the characters' aim of being released. In a holding cell, it is impossible for prisoners to confess their crimes. They are always told to keep silent for their safety. Legally, as the lawyer tells them: "Such is a temporary locker. It's an illegal act to let people in custody spend their night here, let alone gender-mixing"(Ibid, 9).Yet place has been transformed dramatically for the sake of confession.

Confessions go on in Women's Prison. Unlike the holding cell in Younis'Sweet, prison is the place of staying for long periods, according to one's crime. After spending two nights at the holding cell, both Salwa and Laila - the two main characters- move to women's prison. There, they meet many women with different crimes. Salwa and Mona are political activists, Lawahez, the thief, Ansaf and Hind, the prostitutes, Elham, the drug dealer, Shaffika, the murderess, and many others. Being all women, characters begin to tell their crimes to the new comers (Salwa, Laila and Mona). The act of telling has two dramatic functions- to entertain the new comers and to introduce them to the audience as well. These stories are told in a very interesting circular technique; each story leads to the other, forming the

\section{ELLS Vol.8 No.I (168) December 2017}


text and drawing a picture of the prison life. Confession gives relief and makes prisoners admit their crimes whether they are satisfied with their sentences or not.

The sentence is known in No Exit. It is the everlasting prison - hell. Unlike characters in both Younis'Sweet and Women's Prison who admit their crimes and know the reasons for their imprisonment, characters in No Exit pretend to know nothing about the reasons for their being there. The most realistic character is Inez. She confronts both Garcin and Estelle with their lies: "I tell you they've thought it all out. Down to the last detail. Nothing was left to chance. This room was all set for us...Yes; we are criminals-murderers-all three of us. We're in hell, my pets; they never make mistakes, and people aren't damned for nothing"(Sartre, 1989, P.14, 16).Confronted by their realities, the characters begin to confess their crimes. Garcin is a coward who escapes from participating in war. Besides, he is a womanizer who treats his wife badly. Estelle betrays her husband with a young gentleman to whom she bears a baby. The man is so happy with the baby, but Esttle not. She drowns her own baby, and the gentleman commits suicide directly after. Inez is a lesbian lady who has an immoral relation with Florence -the wife of her cousin. Feeling guilty after the tram had hit her husband, Florence put the flat on fire, killing herself and Inez.

Characteristics of place are always referred to as the identity of place, as Edward Relph puts it: "The identity of something refers to a persistent sameness and unity which allows that thing to be differentiated from others"(Relph, 1976 , p. 45). He further marks three components of place identity-"The place's physical setting, its activities, situations, and event and the individual and group meanings 
The Significance of Place in Sartre's No Exit, Enani's Younis'Sweet and El-Asal's Women's Prison

created through people's experiences and intentions in regard of that place"(Seamon\&Sowers, 2008, p.45; Relph, 1976, p .46).

The most noticeable experience gained through place in the three plays (the fourth characteristic) is cooperation and the sense of teamwork since the characters are tied together, may be forever, as in No Exit. The place changes Garcin from being an enemy of people, who declares from the beginning that "Hell is other people!"(Sartre,1989, p.45), to a new Garcin who calls for unity and co-operation : "Alone, no one of us can save himself or herself; we're linked together inextricably...We're chasing after each other, round and round in a vicious circle, like the horse on a roundabout"(Ibid, p.29-30).

By the same token, characters in Younis'Sweet realize that their safety lies in their unity. Mamdouh; the lawyer tells them "Since you are together, you should give each other a hand."(Enani, 1993, p.21). Masoud also warns them of separation lest they should answer differently, and thus, be easily trapped and caught, "We will hurt each other and get separated, then our answers will be contradictory" (Ibid, 19).Near the end of the play, and to tempt them into more confession, the lawyer warns the four male characters saying: "Let's agree on one answer lest we should be hanged together"(Ibid, 31).

Women's Prison lies in the middle ground between No Exit and Younis' Sweet. Characters are neither imprisoned for ever, as in the former, nor are they imprisoned temporarily, as in the latter. Unlike the limited number of characters in the other two plays, characters in Women's Prison are numberless. The author introduces nineteen

\section{ELLS Vol.8 No.I (170) December 2017}


women, a man, and the prison staff, on stage while as many others are offstage. Each woman stays in prison for as different periods as their crimes. Thus, co-operation takes different forms for different reasons besides being safe as in No Exit and Younis'Sweet. One of these reasons is comforting and helping the new comers. Salwa plays this part with her friend Laila and the activist Mona. Other old prisoners introduce themselves by telling their stories and preparing the new ones to the prison life. This is what Rachelle Lopez means when saying that repeated experiences in the same place "facilitates a person's ability to increase their sense of place more than if only a single experience was presented in the area"(2010, p.49). In welcoming the new prisoners, Khokha sends Salwa and her colleagues cigarettes, a pen, a newspaper, a notebook, tea, sugar, among many others. Other prisoners help Ansaf giving birth to her child. Others help each other in fighting Elham and her assistants. In a word, co-operation in this play is a life style.

Co-operation does not only exist among characters inside this closed place, but between the inside and the outside world also. This link between the two worlds is the fifth feature of place here. "In early Modern England" as Thomas Freeman states," there was a transmission of prison writing to the outside as a matter of relative ease"(2009, p. 141).Besides, the presence of servants makes the link easier (Ibid, 142).Such a feature of prison is still working nowadays. In Younis'Sweet prisoners are used to get drugs and their other needs from the sellers passing by the cell window. The sellers insert drugs and everything prohibited inside sweet using secret codes as a means of communication. Through this sweet, the lawyer manages to trap the accused into confession. The lawyer uses also 
The Significance of Place in Sartre's No Exit, Enani's Younis'Sweet and El-Asal's Women's Prison

another means for the same purpose by hinting that every detail about any crime is published constantly in the newspaper, such as the case of the sprout beans, telling Sadia "Seize any opportunity to throw away whatever pieces you get."(Enani, 1993, p. 26-7).

The newspapers are thus another link between the two worlds- the closed inside and the open outside. These newspapers are Salwa's main concern in Women's Prison. When Khokha offers her a piece of drug, Salwa refuses, asking for newspapers, instead. "Very good. This is the favor I'm asking you-to bring me the news every day "(el- Asal, 1993, p. 86). By reading the news Salwa knows that both she and Laila are falsely accused of being spies, working for foreign countries.

Letters are another means of communication between the two worlds. Salwa exchanges letters with both her husband and daughter in a lovely positive way. On the contrary, Laila is cut off from the outside world by a divorce bill. Ansaf is also divorced and prevented from her newly born baby, and thus, kept unconnected.

Servants are a third means of communication between the outside and the inside. Some female secondary characters like Sanyia and Mehalabia in Women's Prison work as servants for the main characters providing them with their needs. Such needs are never answered in No Exit. The characters are supposed to be in another world wherever there is neither inside nor outside. It is hell where things are presented, not for their help, but for torture. The bell does not work, the light is never off, the door never opens, and the valet never answers. There is no food, no water, no sleep, and no eyelids even. Ironically enough, there is a paper knife

\section{ELLS Vol.8 No.I (172) December 2017}


although there are no books, papers or letters. The paper knife echoes Sartre's philosophy of existentialism. Sartre uses it as "an analogy...to illustrate a classic existential axiom for all of human existence"(Heim, 2015, p.131).Besides, the room itself is a Second- Empire drawingroom, "reminding of one of the most shallow and unreal periods in French history"(Loeb, 1961, p.284).

Whether shallow or unreal, this enclosed place is the whole world for the characters in No Exit. For them, there is no outside. When asked about the outside, the valet is shocked:

Valet: Outside?

Garcin: Damn it, you know what I mean. Beyond that wall.

Valet: There's a passage.

Garcin: And at the end of the passage?

Valet: There are more rooms, more passages, and stairs.

Garcin: And what lies beyond them?

Valet: That's all.

Garcin: But surely you have a day off sometimes. Where do you go?

Valet: To my uncle's place. He's the head valet here.He has a room on the third floor. (Sartre, 1989, p.6).

Apparently, there is no outside for characters. There is no exit, as the title refers. Outsideness always signifies hope and future plans. If characters are locked inside these places for their past deeds, they are always looking forward to a better life outside.

This link of the past and the future is a final characteristic of place -in this study. In an article entitled 
The Significance of Place in Sartre's No Exit, Enani's Younis'Sweet and El-Asal's Women's Prison

\begin{abstract}
"The Presence of place in Literature-with a Few Examples from Virginia Woolf'", Sten Moslund comments on Mrs. Dalloway saying:

Whereas the characters in the book are mostly preoccupied by abstract thoughts or thoughts that pertain to an elsewhere or another time and place- memories of the past especially-they seem to be urging for a sense of presence, nonetheless, and this sense of presence seems always to depend on a return of the mind's focus to the present material space as sensed by the body, in other words, a return to some kind of coincidence between the mind's activity with that of the body-subject (2010,p.7).
\end{abstract}

This can be applied to the three selected plays where past memories are mingled with the present and the future.

In Women's Prison, most of these memories concern Laila and her husband Seleem. Each time Laila remembers her husband, the stage directions shift from the prison to Laila's home, "a hole opens through the wall, lighting changes to be a mixture of colours.It reaches another level of the stage showing a setting- a wall with many bright light colors with changing lights. As soon as lights are on this level, Seleem Al-Ansari enters"(el-Asal, 1983, p.74). This action occurs twice during the play. The first takes place at act one, scene four where Laila sadly remembers the day her husband beats her violently. She remembers how foolish she sacrifices her happiness for his and how he never appreciates it.

\title{
ELLS Vol.8 No.I (174) December 2017
}


The second situation occurs at act two, scene two, reflecting Laila's psychological imprisonment with a man she does not love. "A light on Laila's face with a music reflecting Laila's inner imprisonment. She walks slowly and astonishingly. Gradual darkness mixed with light at the other level of the stage through the hole opened before at Lailas' home. Seleem appears getting off his jacket approaching Laila severely. Laila pleas for him:

Laila: No

Seleem: Why?

Laila: I am tired.

Seleem: Every night?

Laila: Unable.

Seleem: But I am able.

Laila: Unwilling.

Seleem: But I am willing.

(Lights faded away through a silhouette. Laila is seen surrendering her body coldly to Seleem. Her crying voice is heard as if a slaughtered animal. She puts a bed cloth at her mouth, not to be heard"(Ibid, p. 146).

Laila's physical imprisonment opens her eyes at the fact of the more dangerous and permanent imprisonment-the prison of mind and spirit. As Salwa once tells her "You are a follower, an ignorant person who never thinks... [Your husband] imprisons you into his cocoon shaping you as he likes. He has brain-washed you. You have become a sheer human figure of no will"(Ibid, p.158-9).

As place inspires Laila into changing her life, it helps Salwa rethink of all her life. Personally, Salwa reflects, "Being enclosed inside this prison makes me rethink of many things, one of them is my relation to my own daughter 
The Significance of Place in Sartre's No Exit, Enani's Younis'Sweet and El-Asal's Women's Prison

Huda"(Ibid, p. 156).Generally, Salwa thinks about the whole society, "When I was outside, I thought we knew and realized everything, but since I entered here I felt that we should rethink about many things"(Ibid, p.180).

Rethinking is always connected with the future, and since there is no future in hell, characters in No Exit never think about their future plans. They never think about their past in an attempt to improve their future. All their concern is about the present moment. Estelle declares, "What's the good of worrying, anyhow? We've got to take what comes to us"(Sartre, 1989, p.10). They are doomed at such closed place for ever as Inez concludes at the last lines of the play, "Dead! Dead! Dead! Knives, poison, ropes- all useless. It has happened already, do you understand? Once and for all. So here we are, forever"(Ibid, p. 46).In this "sealed room in which time becomes only present", the characters have nothing but their past memories that exist also inside other closed places. Mary Witt goes on adding that:

Each one envisions a closed space of particular significance: for the narcissistic Estelle, it is her bedroom full of mirrors, mirrors now "empty" without her reflection; for the would-be man of action but deserter Garcin it is the newspaper office full of men working - and then his wife sitting next to a window; for the sadistic Inez it is the closed, dark, now empty room in which she ensnared Florence (1985, p.134-4).

Lying at the middle ground between the two plays, Younis' Sweet, as a short one act play, provides a short time for the characters to think about any future plans. Yet,

\section{ELLS Vol.8 No.I (176) December 2017}


through the accelerating actions motivated by the lawyer, the reader can guess what the characters will do if released. As soon as Sadia gets out of prison, she gets rid of all the pieces she has. Both Masoud and Atrees promise to guide for Mohammad Ghazal, the main drug dealer, especially after Younis' pretended death. Thus, the place in the three plays helps characters at varying degrees to link their past memories and their expectation for their future and accordingly, their change. People's relationships to their place and how they behave differently in different places is crucial to any human interdisciplinary study (Newell, 2001, p.11-12). People's various relationships to place will be discussed in the following section-sense of place

People's sense of place is their feeling about place. Edward Relph accurately defines people's relationships to their place in terms of "insideness" and" outsideness". "If a person feels inside a place, he or she is here rather than there, safe rather than threatened, enclosed rather than exposed, at ease rather than stressed...the more profoundly inside a place a person feels, the stronger will his or her identity with that place"(Relph, 1976, p. 49; Seamon \& Sowers, 2008, p. 45).Generally, all characters in the three plays experience this change from outsideness to insideness. This change of attitude towards place from hatred to love occurs gradually. In her Doctoral dissertation, Louis Million marks eight stages of this change:" (1) becoming uneasy,(2) struggling to stay,(3) having to accept,(4) securing a settlement,(5) searching for the new,(6) starting over,(7) unsettling reminders, and (8)wanting to resettle."(Qtd. in Seamon\&Sowers, 2008, p. 47).

In No Exit, characters refuse their place, condemn it and criticize it badly. Once they enter the room, they struggle 
The Significance of Place in Sartre's No Exit, Enani's Younis'Sweet and El-Asal's Women's Prison

to escape, calling for the door to be opened. Bit by bit, characters get calm, realizing that such a place is prepared for them beforehand. They have to accept it and adapt themselves making the best of a bad job. Estelle sits on her sofa saying: "We've got to take what comes to us, and I'll stick to the green one. The only one which might do at a pinch"(Sartre, 1989, p.10). Inez also realizes that they have nothing except this place. She tells Estelle:" All you own is here. Would you like that paper-knife? Or that ornament on the mantelpiece? That blue sofa's yours. And I, my dear, am yours forever"(Ibid, p. 32). Moreover, Inez tries to attract Estelle to her side, and both of them possess the place, "We two women will have the place to ourselves"(Ibid, p. 41).Garcin who beats the door several times for exit- exactly like Sa'ad in Youssef Idris' The Critical Moment- stays motionless when the door suddenly opens at the end of the play. He refuses to go out and lingers in, instead, to everyone's surprise. Shortly after, the three characters are tied and stick together inside, refusing to go outside this hell. This action signifies their belonging to the place. For them, it becomes their home even it is hell.

The hell becomes preferable for them to anywhere else. All of them are happy now - for the first time - to be together even if it is hell. The quotation is worth quoted fully:

Inez: Well, Garcin? You're free to go.

Garcin [meditatively]: Now I wonder why that door opened.

Inez: What are you waiting for? Hurry up and go.

Garcin: I shall not go.

Inez: And you, Estelle? [Estelle does not move, Inez bursts out laughing] So what? Which shall it be? Which of

ELLS Vol.8 No.I (178) December 2017


the three of us will leave? The barrier's down, why are we waiting? But what a situation! It's a scream! We're inseparables! [Estelle springs at her from behind]

Estelle: Inseparables? Garcin, come and lend a hand.Quickly.We'll push her out and slam the door on her. That'll teach her a lesson.

Inez [Struggling with Estelle]: Estelle, I beg you, let me stay. I won't go, I won't go! Not into the passage. (Sartre, 1989, p.41-2).

What happens to these characters? What makes them fight each other in order to stick to the place they deeply hate at their first entrance? What pushes Inez to order them "Shut the door. It's ten times hotter here since it is opened"(Ibid, p.42). The answer lies in their sense of place, their happiness to stay in forever. The closed door now signifies their security, among different feelings of "hesitation, temptation, desire, security, welcome and respect"(Bachelard, 1994, p.224).

Such happiness of staying at any place one loves is what Edward Relph calls "existential insideness:

It is the insideness that most people experience when they are at home and in their own town or region, when they know the place and its people and are known and accepted there. Existential insideness characterizes belonging to a place and the deep and complete identity with a place that is the very foundation of the place concept...knowing implicitly that this place is where you belong...there exists between place and person a strong and 
The Significance of Place in Sartre's No Exit, Enani's Younis'Sweet and El-Asal's Women's Prison

profound bond"(Relph,1976,p.55; Seamon

\&Sowers, 2008, p.45).

This sense of place reaches its climax in Women's Prison. When asked about her sentence, Shafika replies: "Long-life prison. Prison becomes my home and shelter. I forget about the outside world. I am fully satisfied with my being here, among the people I love"(el-Asal, 1993, p.57). Another example is Lawahez, the thief. She will be released soon, but she is sad to leave the prison, telling Laila: "At the beginning, all of us were so sad like you, but as the time passes, we get accustomed to prison and love it.Here I am, I am going to leave tomorrow but so sad to leave the people I long love"(Ibid, p.40).Moreover, the prison can be a place of love memories as in Salwa's case. She tells Laila:" Since I enter the prison, I remember those first lovely days of my marriage life. I was imprisoned in women's prison and my husband in men's prison. We exchanged love letters there and got married as soon as we were released"(Ibid, p.150).

Release is always expected since the characters are still in the holding cell in Younis' Sweet. Sadia gets released while the other four male characters go to prison. All of them are used to such a life; they enter and get released repeatedly. These characters have no particular feelings towards any place. This is what David Hummon terms as "relativity" people's ability to "identify with more than one place...they feel "at home" anywhere instead of in a specific place" (Hummon, 1992, p.273; Cross, 2001, p.11).

Relativity is one of the relationships to place. Another relation is "narrative". Jennifer Cross defines it as "Learning about a place through stories, including: creation myths, family histories, political accounts, and fictional

ELLS Vol.8 No.I (180) December 2017


accounts"(2001, p.3). The common impression about prison, according to this definition, is the place of torture. When Garcin faces the valet with his own impression about the place in No Exit, the latter replies:" Really, sir, how could you believe such cock-and-bull stories? Told by people who'd never set foot here?"(Sartre, 1989, p.3-4). Shortly after, Garcin realizes that the sense of place has nothing to do with its physicality. Thus, the real torture is not what one hears about, it is experienced. When he experiences imprisonment, Garcin concludes that hell has many forms rather than physical torture, namely "Hell is - other people!"(Ibid, p.45).

Narrative relation to place is also refused by Shafikka in Women's Prison. Shafikka (who kills her husband upon seeing him making love to her daughter-in-law) introduces new concepts of relief, imprisonment, release and happiness, contrary to what is commonly known and narrated. Her conversation with Laila has to be quoted fully for its significance.

Laila: Relieved now?

Shafikka: Yes, when I killed him, I got rid of my pains, got relief and got out of prison.

Laila: How come? You are inside the prison and will stay forever.

Skaffika: No, darling. This is not the prison. The prison is to be kept in darkness, is heart-breaking and insafety.Prison is confusion and sadness...But once everything is crystal clear, you get released...After killing him, I felt happiness and peace of mind.

Laila: Happiness? Here, inside prison? 
The Significance of Place in Sartre's No Exit, Enani's Younis'Sweet and El-Asal's Women's Prison

Shaffika: Yes. When you get rid of your worries and take revenge, you will be happy anywhere, inside or outside prison. Nothing matters after that. (el-Asal, 1993, p.171.).

For Shafika,"The place of punishment is potentially the place of salvation. Those who recognize this life as a prison will be better able to receive divine grace, to decipher the image on the wall, to be saved"(Witt,1985, p.7).

The words of Shaffika reflect the core of this paper. They provide a good summary of the whole paper. These words define the three corners of the triangle of this study definition of place, sense of place and spirit of place. The words echo the fact that people can belong to any place depending more on its sense than its spirit. In a word, people may be connected to any place since they are happy. It is astonishing that the characters in the three selected plays find their happiness inside closed places known for their negative spirit. Although the spirit of place is the same in the three plays, the characters' sense of place differs according to personality, experience, expectation and the time spent. The much time spent in any place and the repeated experiences in the same place deepen people's bond to this place. Part of people's love of any place is related to their love of the people inhabiting it. Thus, people and place are two attracting poles. The place with its own spirit affects people's life greatly. By the end of this paper, it can be safely said that the place is the hero in the three selected plays. It captures all characters together in a net of relationships where they interact with themselves and the place as well. Place, thus, deserves to be given more attention in literary studies. A great bulk of literary studies has tackled the poetics of place. It is the right time now for these studies to focus more on place as one of the most dramatic elements,

\section{$\begin{array}{lllll}\text { ELLS Vol.8 No.I (182) December } 2017 & \end{array}$}


Dr. Ebtesam M.M. El-Shokrofy

applying different studies of place; geographical, sociological, psychological, and environmental, among many others. 
The Significance of Place in Sartre's No Exit, Enani's Younis'Sweet and El-Asal's Women's Prison

\section{Works Cited}

Bachelard, Gaston. (1994).The Poetics of Space. Translated from the French by Maria Jolas.With a new foreword by John R.Stilgoe.Boston, Beacon Press.

Buttimer, A. \& Seamon, D. (Eds.) (1980)."The Human Experience of Space and Place". Geographical Journal 147(1), January,1980.pp.14165.https//www.researchgate.net/.../23878711 4_The -Human -Experience-of-Space-and-Place.

Casey, S., Edward. (2001)."Between Geography and Philosophy: What does it Mean to be in the place-world?"Annals of the Association of American Geographers.Vol.91, No.4 (Dec., 2001).pp.683- 693. Oxford.Taylor\&Francis, Ltd. On behalf of the Association of American Geographers. Stable

URL:http://www.jstor.org/stable/3651229.Accesses:29/5/2014

Cresswell, Tim. (2004).Place: A Short Introduction.Oxford.Blackwell Publishing Ltd.

Cross, Jennifer E. (2001)."What is Sense of Place?" The $12^{\text {th }}$ Headwaters Conference. Western State ColoradoUniversity.Western.edu/sites/cross headwaters xii.pp.114.

Daniels, Stephen. (1992)." Place and the Geographical Imagination". Geography, Vol.77, No.4 (October, 1992), pp.310322. Geographical Association. Stable URL:http://www.jstor.org/stable/40572252.Accesses:6-10-2012

\section{ELLS Vol.8 No.I (184) December 2017}




\section{Dr. Ebtesam M.M. El-Shokrofy}

El-Asal, Fatthiya. (1993).Women's Prison. (Sijin Al-Nesaa). General Egyptian book Organization.

Enani, M., Mohammad. (1993).Younis' Sweets and Other Plays (Halawat Younis). General Egyptian book Organization.

Freeman, S, Thomas. (2009)." The Rise of Prison Literature". Huntington Library Quarterly. Vol.72, No.2 (June, 2009), pp.133146. University of Pennsylvania Press. Stable

URL:http://www.jstor.org/stable/10.1525/hiq.2009.72.133.Access es:22-8- 2016.

Harvey, David. (1996)."From Space to Place and Back Again". Published in Justice, Nature and the Geography of Difference. Cambridge, Mass: Blackwell.

Heim, Caroline \&Hiem, Christian. (2015)." No Exit from the Gaze: Sartre's Theory Facilitated Through Aspects of Meisner's Practice". Journal of Dramatic Theory and Criticism.Vol.29, no.2, spring 2015.pp.127-145.Published by Department of Theatre.University of Kansas.DOI:10.1353/dtc.2015.0001

Hummon, M., David (1992)."Community Attachment: Local Sentiment and Sense of Place". Chapter 12.pp.253-278. Edited by Irwin Altman and Setha M.Low.New York, Plenum Press.

Hunziker, Marecl, Buchecker, Mttian and Harting, Terry. (2007)."Space and Place - Two Aspects of the Human Landscape". Published in A Changing World. Challenges for Landscape Research.F.Kienast, O.Wild \&S. Ghost (eds.).pp.4762.Springer.Corresponding author: Marcel Hunziker Lippard,Lucy.(1997).The Lure of The Local: Senses of place in a multicentered society. New York. The new press. 
The Significance of Place in Sartre's No Exit, Enani's Younis'Sweet and El-Asal's Women's Prison

Loeb, Ernst. (1961)."Sartre's No Exit and Brecht's The Good Woman of Setzuan: A Comparison". Modern Language Quarterly.22 (3):pp.283-291.

Lopez, Rachelle. (2010)."Sense of Place and Design".Focus.Vol.7. Issue 1 Article 16.pp.46-52.Available at:http://digitalcommons.calpoly.edu/focus/vol7/iss1/16.

Low, Setha M. (1992)."Symbolic Ties That Bind: Place attachment in the Plaza" Place Attachment. Chapter 8.pp.165185.Edited by Irwin Altman and Setha M.Low.New York, Plenum Press.

Low, Setha M. \& Altman, Irwin. (1992)."Place Attachment: A Conceptual Inquiry". Place Attachment. Chapter 1.pp.1-11.Edited by Irwin Altman and Setha M.Low.New York, Plenum Press.

Moslund, Sten. (2010)."The Presence of Place in Literature - with a Few Examples from Virginia Woolf".Aktuel Forskning Ved.ILKM. ISSN 1903-5705.7 Dec.2010.pp 1-11

Newell, H. William. (2001)."A Theory of Interdisciplinary Studies". Issues in Integrative Studies.No.19, pp.1-25.

Relph, Edward. (1976).Place and Placelessness.London.Pion Limited.

Sartre, Jean-Paul. (1989).No Exit and Three Other Plays .New York. Vintage International.Vintage Books.

Seamon, David \&Sowers, Jacob (2008)."Place and Placelessness, Edward Relph". Published in Key Text in Human Geography.P.Hubbard, R.Kitchen \&G.Vallentine, eds.London.Sage, 2008, pp.43-51.

Tuan, Yi-Fu. (1979)."Space and Place: Humanistic Perspective".

ELLS Vol.8 No.I (186) December 2017



and G.Olsson.pp.387-427.

Witt, Mary Ann Frese. (1985).Existential Prisons: Captivity in Mid - Twentieth -Century French Literature.Durham.Duke University Press. 
The Significance of Place in Sartre's No Exit, Enani's Younis'Sweet and El-Asal's Women's Prison 